
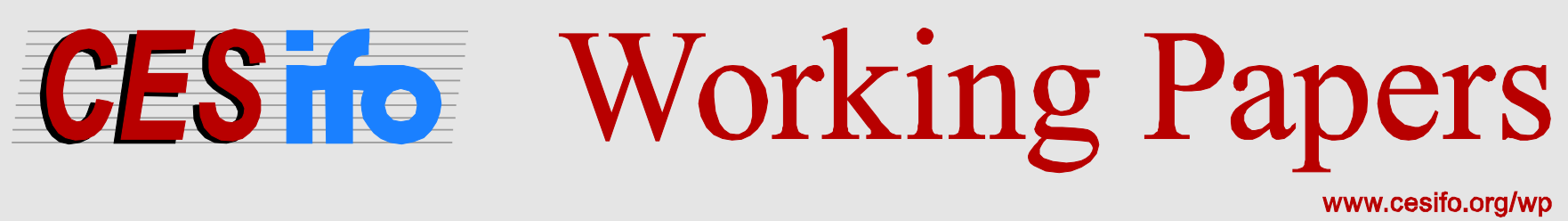

\title{
Rig Services and Taxation
}

\author{
Petter Osmundsen
}

\author{
CESIFO WORKING PAPER NO. 4973 \\ CATEgory 1: PuBliC FinANCE \\ SEPTEMBER 2014
}

An electronic version of the paper may be downloaded

- from the SSRN website:

- from the RePEc website:

- from the CESifo website:

wWw.SSRN.com

Www.RePEc.org

www.CESifo-group.org/wp

\section{CESifo}




\title{
Rig Services and Taxation
}

\begin{abstract}
A long period of rig scarcity and high rates has led to innovation in the procurement of rig services and in relationships between oil companies and rig contractors. Discussions have been conducted on joint ventures between companies and contractors, for instance. This paper describes and analyses such a solution from a taxation perspective. Could a joint venture pose problems for revenue capture from the petroleum sector? Challenges in taxing drilling services - including recently adopted British restrictions on determining internal charter rates for drilling units - are also analysed. In addition to analysing topical issues related to taxation and rigs, the paper makes a general contribution by highlighting the connection between taxing rig services at oil-company and rig-contractor levels, and by placing rig taxation in a broader resource management perspective.
\end{abstract}

JEL-Code: L600, K400, M110, H250, H270.

Keywords: rig services, transfer pricing, tax planning.

Petter Osmundsen

Department of Industrial Economics, Risk Management and Planning

University of Stavanger

Norway - 4036 Stavanger

Petter.Osmundsen@uis.no

\section{August 2014}

Thanks are due to a number of specialists in petroleum-related government agencies, the oil industry and the supplies sector for useful suggestions and comments. Norwegian Research Council is thanked for funding. 


\section{Introduction}

The oil industry faces a sharp increase in costs, which threatens profitability and new projects. The biggest growth has been in drilling. Rig rates have tripled in the space of a few years. ${ }^{2}$ In an effort to reduce rig rates, the oil companies are investigating whether new ways of organising the relationship between themselves and the rig contractors - including changes to risk-sharing and ownership - can increase the supply of units at acceptable cost.

Examples and cases presented in the paper are taken from the Norwegian Continental Shelf (NCS). Since all petroleum provinces have experienced rising rig rates, since major players in both among oil companies, rig companies and oil services are present on the NCS, and since the contracts for rig hire mostly follow an international standard, the findings in the paper are likely to have global relevance.

The scarcity of rigs, combined with a considerable lengthening in contract durations, has led to a number of interesting examples of innovation in contractual and organisational patterns for drilling on the NCS. These include new types of incentives in drilling contracts, small oil companies joining forces to establish a rig consortium, and vertical integration where oil companies own rigs. It is not obvious that all these new trends would survive a downturn in the market for rigs and oil services, but they nevertheless represent interesting examples of innovation in the shaping of contractual and organisational patterns. Very high rig rates on the NCS mean that this type of adaptation and experimentation is welcome.

The paper looks at topical issues related to rigs and taxation of oil companies and rig contractors. It also highlights the relationship between taxing these two tax subjects. In addition, taxation is placed in a broader resource management perspective. With specific regard to oil company taxation, possible challenges created by joint ventures between oil companies and rig contractors are discussed. Another topical issue related to rig contractor taxation raised in the paper is the cap (the bareboat charter tax plan) recently imposed by the UK on internal rig charter rates.

A distinction can be made between fixed and mobile drilling units. This paper addresses mobile units or rigs. Licences have normally always owned the drilling units permanently installed on platforms. Crews are hired from drilling contractors, and maintenance is usually also contracted out. The mobile rigs operating on the NCS have been owned by a rig contractor and chartered in to conduct drilling operations. Such units can be divided into two main categories - jack-ups standing

\footnotetext{
${ }^{2}$ Osmundsen et al (2012, 2013).
} 
on the seabed and semi-submersible floaters. Drill ships also exist, but only one of these is found on the NCS.

\section{Chartering rigs from associate companies. Affect on revenue and resource management}

The paper addresses the treatment of rig services in oil company taxation. This is an important topic for international petroleum taxation, owing to the high level of rig rates. Tax exemption of rig services is usually fairly straightforward, since the normal position is that oil companies and rig contractors are independent entities - ie, arm's length prices exist. However, new challenges emerge with a trend towards oil companies owning rigs and the ownership of rigs organised as joint ventures between rig contractors and oil companies. With rig ownership located in tax havens, oil companies may then have an incentive to set a high rig rate in order to shift profits out of heavily taxed petroleum provinces.

Rig contracts and organisational patterns for rig ownership are examined, along with available academic literature on rig contracts, such as Corts (2000), Corts and Singh (2004), Kaiser and Snyder (2013) and Osmundsen et al (2006, 2008, 2013). Extensive meetings have been held with key specialists in oil taxation offices, oil companies and rig contractors. Rig charters have been studied and rig rates analysed.

Various models exist for rig ownership. The big contractors are themselves active in planning taxefficient models which allow them to retain part of the gain. Economic aspects of an organisational solution for rig procurement, whereby a licence owns a rig together with the contractor through a special purpose entity, are discussed below. This will be referred to here as a joint venture. Various interpretations of the joint venture concept exist. A joint venture which owns rigs abroad can be regarded as a conventional company. Such a construction on the NCS is not regarded as a company under Norwegian law, but merely as a form of collaboration. But it is naturally conceivable for an offshore joint venture to own rigs, and for participants to recognise their respective interests in their balance sheets in the same way as their interests in an oil field.

\subsection{Effect on petroleum taxation}

If the rig is owned by an offshore joint venture or by an oil company with activity on the NCS, costs will be determined as the sum of operating expenses and depreciation on the basis of actual 
expenditure and financing. That can basically yield a substantial saving in cost terms, given the barriers to entry in the segmented Norwegian rig market and today's level of rates. With this option, the whole expected saving occurs under the 78-per-cent tax regime. Should the rig be owned by a separate company, an internal price must be established. This will probably lie close to actual observable prices, basically well above long-term costs. Should a sufficient number of rigs be owned under internal conditions, internal rates could conceivably move close to cost-based rates in that independent rates are pulled down. Another consideration is the effect of net cash flows in the two cases, since depreciation and financing apply when the rig is owned directly but are built into a rate in an internal charter.

Should a licence own a rig together with the contractor through a special purpose entity, the licence would be chartering partly from itself. An example is Norway’s Jordbær (now Knarr) licence, where British Gas (BG) is operator and the other licensees are large companies. Teekay supplied a floating production, storage and offloading (FPSO) unit. Instead of chartering the latter, the plan was to own it through a special entity belonging wholly or partly to the licence or to the licensees directly. Teekay would also hold an interest. In other words, the licence would be chartering wholly or partly from itself - an internal transaction. The details of the planned arrangement were not made public. The government gave negative signals about this contractual model, which could have contributed to the rejection of the plan. Instead, a traditional charter was entered into but the licence guaranteed Teekay’s loan. The BG/licence guarantee for Teekay's borrowing costs and the savings this yields are interesting. It is probably impossible to provide such a guarantee free of risk, but the risk for the licence could be limited to disasters (in other words, what is built never comes on stream) and is accordingly one which the licence perhaps could and should take in light of the substantial saving in financial costs such a guarantee can provide.

As with all other internal transactions involving different tax jurisdictions, questions arise related to tax arbitrage. Since rig contractors and oil companies operate in two different tax regimes, new tax control challenges could potentially be created. The parties must accordingly first clarify whether this form of organisation would be accepted by the government. It is accordingly interesting to conduct a socio-economic assessment of joint ventures in the rig sector.

Evaluating this special form of rig ownership must be weighed in this context against the way it affects the overall goals of government petroleum policy. In the present case, it would be natural to split these into several specific and delimited sub-goals:

1) secure the availability of rigs and acceptable rig rates

2) control of the tax base 
3) legal enforceability

4) avoid distorted decisions

1) Secure the availability of rigs and acceptable rig rates

The backlog in drilling production wells documented by the Improved Recovery Commission in 2010 provides a clear indication of rig scarcity on the NCS. However, it could be objected here that the overall level of activity is now very high, and that the problem in the short term could have been an overemphasis on exploration at the expense of production. An increased supply of rigs will be beneficial in any event with a view to keeping down rates. With more stringent application of safety requirements, Norway has placed itself in a difficult position on the rig side. The Norwegian rig market has been isolated (segmented) from other sub-markets, and the supply of such units on the NCS is in practice limited. See the Rig Commission (2012) and Osmundsen (2012). Moving rigs to Norway is expensive, and building units dedicated to the Norwegian market calls for careful consideration. Existing rig contractors are not necessarily dissatisfied with this state of affairs probably the opposite as it provides technical trade barriers - but high rates threaten new developments and activities on mature fields. Although many new rigs are now on their way to Norway, the government needs to be careful in introducing new regulations and requirements which could weaken the supply of such units for the NCS.

\section{2) Control of the tax base}

Structures involving a joint venture could present a built-in threat to the tax base in the petroleum sector. The joint venture company is subject to the mainland tax regime (27 per cent tax rate) or possibly to a tax haven with virtually no tax, while the hire is deducted under the petroleum tax regime (78 per cent). When the licence owns the rig, it will deal to some extent (depending on the rig contractor's equity interest) with itself (internal transaction). Identifying owner constellations where all the parties will be served by the highest possible rig rate is then not difficult, since profits are thereby transferred from high petroleum taxation to moderate mainland tax or even zero tax (tax-induced profit shifting). This is clearly a problem for the government's primary goal of revenue capture. The question is whether this problem can be alleviated by forbidding certain company structures and ownership forms, or by other means. 
Norway’s Petroleum Tax Office (OSK) has not done much work on transfer pricing of rigs since these have so far normally been chartered between independent parties. However, it is possible to find rates and second-hand values for rigs in updated databases (RS Platou, for example). In addition, the OSK has access to independent rates from rig charters by other companies, but these often involve secret comparables which prevent revealing the identities of the parties to the transaction, and the burden of proof must be assessed in each case. Internal pricing of rigs should be a job with a normal degree of difficulty in terms of the OSK's tax assessment of oil companies, providing the contractual terms do not deviate too much from transactions available for comparison. Charter terms will be investigated and assessed by the tax authorities, and the regulations and the instruments in the internal pricing toolbox can be used to arrive at a correct result from the government's perspective. The companies should carry out a proper risk assessment. If a long-term charter is involved, finding a relevant basis of comparison could be a challenge. Since the licence takes on operational risk in a joint venture, the rate must be set at a lower level than between independent parties. Adjustments can be made for this. Moreover, a comparison of rig rates must be undertaken with comparable types, and only a few units are capable, for example, of working in a harsh environment. The comparison must also be made for fixtures at the same time and for the same duration. Rates can fluctuate a great deal in just a few months. Contractual terms (downtime, guarantees, bonuses and so forth) vary between contracts, and adjustments must be made for that when comparing rates. For an empirical analysis of the relationship between rig rates and contract terms, see Osmundsen et al (2008, 2012, 2013).

If the operational risk is assigned to a special purpose entity, the oil company will pay a normal rate. Should it be assigned to the oil company, on the other hand, and the contract is with a company in a joint venture (special purpose entity), the rate to the oil company should be lower to reflect the risk. $^{3}$ In both cases, the two sides can naturally do better from overpricing because of the tax wedge. If the capital injection in the special purpose entity is not pro rata with the equity interest, the assessment is likely to be complicated. To the extent that the rig is to be chartered out to a joint venture involving independent parties, however, a control will exist.

A regulatory approach which might simplify taxation could be to restrict rig ownership to countries where Norway has agreements on exchanging tax information, and where such arrangements function satisfactorily in practice. The OSK would then have easier access to information about the company which owns the rig. The Global Forum on Transparency and Exchange of Information for Tax Purposes is an initiative under the OECD which conducts peer reviews to check how effective

\footnotetext{
${ }^{3}$ For a long-term charter with the operational risk assigned to the licence, it can be argued that a comparison with a leasing arrangement would be just as appropriate, adjusted for such risks as cost overruns and residual value.
} 
the exchange of information between countries is in practice. This forum has 120 members, including a number of tax havens. However, it is not desirable to implement effective taxation by prohibiting specific contractual structures, whether in the petroleum regulations (including company-specific decisions) or in the tax regulations administered by the Ministry of Finance. This type of provision could generally limit value creation, and in this case specifically restrict the supply of rigs to the NCS. Adopting provisions of this kind is also unlikely to be possible because they would conflict with the World Trade Organisation (WTO), and bilateral trade agreements.

\section{3) Legal enforceability}

A legal approach to the problem would typically be that this is fundamentally a valuation issue. From a legal perspective, great caution would be exercised in limiting the freedom to enter into agreements and contracts - not only for reasons of principle, but also for practical considerations in that this would represent a type of command economy which may restrict innovation and value creation. Moreover, legal experience suggests it would be hard to see how prohibiting certain types of contracts or companies could prevent such an adjustment if the players really want it. Would not such prohibitions be very easy to circumvent regardless? By changing the owner composition slightly, by dividing the investment unequally - perhaps supplemented by agreements on unequal division of dividends - it is possible to argue that a third-party pricing is nevertheless involved. The company can also be registered abroad, and structured in such a way that its ownership cannot be identified.

\section{4) $\quad$ Avoid distortions}

A neutral tax system is conditional on effective enforcement by the tax authorities, including control of various types of internal pricing. Distortions could in principle otherwise arise. In this case, internal pricing problems are likely to be manageable. If that is not the case, challenges associated with tax leakage would be faced. The amounts involved are relatively large, given the high level of rig rates, but the OSK would in any event have a certain degree of control. So tax leakage must be regarded as limited. It is possible that the potential for tax adjustment on the rig side could also influence real-life decisions, but I cannot come upon any obvious examples here. The internal pricing problem usually relates to revenue leakage rather than to distortions to economic adjustments.

Organisational solutions in the rig sector have often been highly controversial. Normal rig chartering is designed to suit big oil companies best, and a certain degree of innovation could be required for new players on the NCS. Risk exposure for the rig contractors is also countercyclical, 
which is clearly unfortunate. When oil prices and the level of activity are high, the rig contractors are opposed to bearing risk and they have the bargaining power to decline it. But they are often pressured into doing so when times are bad and their ability to bear risk has been reduced. A potential could exist for new and improved solutions for rig acquisition, both organisationally and contractually. The government should exercise caution in prohibiting such innovations, particularly considering the scarcity which prevails at times in the special Norwegian market for rigs. At the same time, revenue capture by the government must clearly be safeguarded. The OSK does a good job here. Signals can by all means be sent that certain company structures will be closely monitored. However, banning specific company solutions on the basis of inadequate studies does not seem to be the right approach.

\subsection{Effect on rig taxation}

I have so far described the job done by the OSK when dealing with rig rates in relation to the taxation of oil companies. The challenges facing the Central Office for Foreign Tax Affairs in taxing rig contractors are more demanding. The normal approach for groups delivering drilling services to the petroleum industry on the NCS is to organise this activity by establishing a foreign company - usually in a country with little or no tax - for the purpose of acquiring and owning a specific drilling rig. See Dragvold (2010). This unit is then chartered to a Norwegian-registered company which conducts the business of securing and executing drilling assignments. Such an organisation means that the rig owner is not subject to Norwegian taxation.

Contracts between rig owners and operators are often designated bareboat charters. See Kolter (2006). In its pure form, the "bareboat" term means that the owner transfers full control of the unit to the operator. The licence in a possible joint venture would itself employ a different subcontractor to operate and maintain the rig. Rig contractors are (almost) always organised in the same way - in other words, they do not charter rigs to the oil company but deliver drilling services from their operating arm. The latter do not normally own the rigs they use, but charter them from associated owner companies in the same group. Internal pricing of such charters is unusually difficult. No comparative basis exists - there are no companies which only own rigs for chartering to other operators.

The exercise to be undertaken when assessing rig companies for tax is to split such contracts into a separate payment for the rig (charter rate) and another for services delivered by using the unit. That makes it necessary to determine what charter rate an operating company could theoretically have 
negotiated with the owner. This is based on analyses of functions, assets, risks, market and the distribution of negotiating power between operating and owner companies. Furthermore, the rates used for comparison (drilling services or time charters) are normally agreed in such a way that the operating company only charters the rig for a period corresponding to the contract with the oil company (back-to-back). The long-term market risk accordingly lies with the owner company. That could justify the rig owner taking most of the profit in good times, while the operating company has relatively stable earnings. Put bluntly, this means that operating companies located in Norway pay little tax, with the bulk of the profit being allocated to the rig owner based in a tax haven or a country with special tax terms for vessel owners.

The position for joint ventures appears to be different. The charter between the joint venture and the licences must probably be long-term, and will present the licences with a capacity utilisation risk. Opportunities for tax planning could be undermined, which might reduce interest in such deals.

\section{UK tax change for the rig sector}

The UK authorities recently tightened up the taxation of rigs and support vessels. As previously notified, the 2014 budget imposed restrictions on the internal charter rate for such units in rig companies. ${ }^{4}$ If the charter rate is sufficiently high, all profit is transferred to the owner in a tax haven. To ensure that the profit goes to the UK operating company, the British have imposed a ceiling on the charter rate of 7.5 per cent of historical cost for internal company transactions where the owner is located in a tax haven.

Andrew Cox, corporate tax partner in Deloitte, estimates for Upstreamonline.com that the revenue capture effect with the tougher tax rules for rigs is GBP 500 million. It must be added here that this is a partial view of the rig sector. Tax incidence - the way tax increases are passed on in prices - is a complicated field of study. Nevertheless, a special tax measure of this kind in the UK can clearly be transferred to the oil companies. That will affect tax revenues from these companies directly, and indirectly through a decline in activity. Such a decline is likely, given that the petroleum industry is already struggling with high costs after many years of boom. The net effect is therefore uncertain. Considering that the effective tax rate in the oil industry is substantially higher than in the rig sector, too, the net tax effect for the UK from this measure will probably be negative. However, the British petroleum tax regime must be regarded as a whole, and the UK has introduced a number of tax concessions for marginal and mature petroleum projects. The latest is a special tax deduction for

\footnotetext{
${ }^{4}$ Upstreamonline.com, 19 March 2014, 16.37.
} 
fields with particularly high temperature and pressure. ${ }^{5}$ That could help to counter a fall in activity as a result of higher tax-induced rig rates.

The British tax change for rigs also raised a number of objections in principle. My understanding is that this means similar decisions are not relevant in Norway. The proposal is clearly controversial because other countries maintain that such national measures undermine double taxation treaties. The change is directed at the pricing of services between related companies (internal pricing). Internal prices are covered by article 9 of the OECD's model agreement, which permits a country to make changes to tax assessments if non-market pricing has been used. Introducing stereotyped restrictions on the ability to deduct a specific cost category from tax will increase taxable income for the source state (in this case the UK) at the expense of the home state, without a genuine test of whether the charter rate is determined by the market and thereby represents legitimate income for the recipient company.

The challenge in taxing mobile tax objects is that the recipient company (state) generally speaking imposes no taxes on such revenues. That applies not only to tax havens but also to states with various forms of tax-free regime (such as the Norwegian shipowning tax system, although this does not include rigs). To a not insignificant extent, special agreements are also entered into with individual companies which are awarded privileges - and that happens in several OECD countries.

\section{Conclusion}

Tax control of rig ownership organised as a joint venture presents challenges, but the availability of panel data sets of rig rates mean the problem is smaller than for a number of other tax issues. The OSK has not worked much on transfer pricing for rigs, since the normal position hitherto has been chartering between independent parties. However, rates and second-hand values for rigs can be found in updated databases (such as RS Platou). The challenge is to adjust for different rig types, charter durations, timing of charter fixture, contractual terms and so forth.

Awareness that this type of company structure will attract the attention of the OSK will impose natural limits. The OSK can also subsequently cut through or amend internal pricing, and impose a tax penalty.

The joint venture construction may pose a built-in threat to the tax base in the petroleum sector. A joint venture is subject to the tax regime of the country of registration, possibly a tax haven with

\footnotetext{
${ }^{5}$ Upstreamonline.com, 19 March 2014, 13.09.
} 
virtually no tax, while the charter rate is deducted from taxation in the petroleum regime where the resource rent tax is high. When the licence owns the rig, it will to a certain extent (depending on the rig contractor's holding) deal with itself (internal transaction). It is not difficult then to identify owner constellations where all parties will be served by the highest possible rig rates, since this involves transferring profits from high petroleum taxation to moderate or zero national taxation (tax-induced profit shifting). This is clearly problematic from the perspective of the government's primary goal of revenue capture. The question is whether this problem should be dealt with by banning specified company structures and ownership models, or whether it can be overcome in other ways. Implementing effective taxation by precluding specific contractual structures is not desirable. Generally speaking, such provisions could limit value creation and specifically curb rig availability. Actions of this kind would probably also be impossible because they will come into conflict with the WTO and bilateral trade agreements. The challenges related to joint ventures can be handled in the tax assessment of oil companies. No basis accordingly exists for prohibiting these types of structure.

The impression is that the oil companies show little interest in this solution. A number of considerations probably account for this. They are uncertain whether the government will overrule the tax aspects of such arrangements, and are therefore reluctant to enter into them while the tax position is unclear. In addition come more fundamental objections. Joint ventures may involve unclear responsibilities, and assigning sole ownership of the rig to one of the parties could be a neater solution.

\section{References}

Dragvold, P (2010), “Utleie av borerigger i konsernforhold - felles virksomhet?”, Skatterett 4, 375390.

Corts, K (2000), “Turnkey Contracts as a Response to Incentive Problems: Evidence from the Offshore Drilling Industry”, working paper, Harvard University.

Corts, K S and Singh, J (2004), “The Effect of Repeated Interaction on Contract Choice: Evidence from Offshore Drilling”, Journal of Law, Economics and Organization 20 (1), 2004, 230-260.

Improved Recovery Commission (2010), Økt utvinning på norsk Kontinentalsokkel, report from an expert commission appointed by the Ministry of Petroleum and Energy, published 22 September 
2010, chaired by Knut Åm: http://www.regjeringen.no/nb/dep/oed/dok/rapporter/2010/Oktutvinning-pa-norsk-kontinentalsokkel.html?id=615841.

Kaiser, M J and Snyder, B F (2013), "The offshore drilling industry and rig construction in the Gulf of Mexico", Lecture Notes in Energy, vol 8, Springer-Verlag, London.

Kolter, H (2006), “Internprising - praksis ved Sentralskattekontoret for utenlandssaker”, Skatterett 2, 155-174.

Osmundsen, P (2012), "Innelåsning og markedsmakt i det norske riggmarkedet”, Samfunnsøkonomen 8, 32-42.

Osmundsen, P, Rosendahl, K E and Skjerpen, T (2013), “Contract Structure and Rig Rates”, IAEE European Conference 2013, Dusseldorf, 18-21 August 2013.

Osmundsen, P, Skjerpen, T and Rosendahl, K E (2012), “Understanding rig rates”, proceedings, International Association for Energy Economics (IAEE), Venice, 9-12 September 2012.

Osmundsen, P, Sørenes, T and Toft, A (2008), “Drilling Contracts and Incentives”, Energy Policy 36, 8, 3138-3144.

Osmundsen, P, Toft, A and Dragvik, K A (2006), "Design of Drilling Contracts - Economic Incentives and Safety Issues”, Energy Policy 34, 2324-2329.

Rig Commission (2012), Økt bore- og brønnaktivitet på norsk sokkel, report from an expert commission appointed by the Ministry of Petroleum and Energy, 19 December 2011. Published Thursday 16 August 2012:

http://www.regjeringen.no/upload/OED/pdf\%20filer/bore_og_br_aktivitet_riggutvalget_2012.pdf. 